\title{
Study on Retrofitting of Heritage Structure: Construction \& Problems
}

\author{
Ashu Anand \\ (Student) \\ M-Tech Structural Engineering, \\ A.P.J. Abdul Kalam University, Lucknow, Uttar Pradesh. \\ B S Tyagi \\ Head of Department, \\ Radha Govind Group of institutes, Meerut, \\ Uttar Pradesh.
}

\begin{abstract}
India is the land of heritage structure. It contains variety of heritage monuments and structure which are need to be conserved. Since we all know that India is country which is at high risk of been subjected to natural disaster such are earthquake, floods, cyclones etc more often every year in past 2 decade evidently. This phenomenon is increasing day by day. This paper draws the attention towards general problems encountered in development plan of heritage conservation. Heritages conservation lacks in methodologies used to rehabilitate, understandability of structural as well as material aspects. Also the economical aspects are another major part which hinders the initiative taken towards retrofitting of heritage building. Looking in scenario government of India has already started taking initiatives by making laws and making authorities appointing tasks etc. This paper discusses briefly about Geometrical layout \& Material understanding of Heritage structure.
\end{abstract}

\section{INTRODUCTION:}

According to Geologists and Seismologists the Indian plate is sinking into Asian plate at the rate of $47 \mathrm{~mm} /$ year which is the major reason behind the increase in frequencies of seismic activities.

Indian States such as Delhi, Gujarat, Uttar Pradesh etc almost half the land mass of Indian mainland suffers several earthquakes from mild to moderate to high magnitude every year.

Recently in past 2 to 3 months are National capital region has suffer around 11 earthquakes followed by Gujarat, Jammu Kashmir which is an alarming situation.

Both Arabian Sea and Bay of Bangal coastlines were hit by major cyclone Nisarga and Amphan respectively one after the other which affect our major city such as Mumbai.

Table no. 1 : Cyclone

\begin{tabular}{|l|l|l|}
\hline Slno. & Name of Cyclone & Intensity $\mathbf{~ k m} / \mathbf{h}$ \\
\hline $\mathbf{1}$ & Amphan & $240-260$ \\
\hline $\mathbf{2}$ & Nisarga & $110-120$ \\
\hline
\end{tabular}

Although according to Natural disaster management Authority (NDMA) India has possibility to get exposed to high risk every year.

\author{
Anuj Anand \\ Field Engineer, \\ Secon Pvt. Ltd, Bangalore, \\ Karnataka \\ Rajeev Verma \\ Assistant Professor, \\ BSA College of Engineering and Technology, \\ Uttar Pradesh.
}

Table No. 2 : Natural Disaster

\begin{tabular}{|c|c|c|}
\hline Slno. & Natural Disaster & Land Mass \\
\hline $\mathbf{1}$ & $\begin{array}{c}\text { Exposed to earthquakes (mild } \\
\text { to severe) }\end{array}$ & $58.6 \%$ \\
\hline $\mathbf{2}$ & Flood \& River Erosion & $12 \%$ \\
\hline $\mathbf{3}$ & Drought & $68 \%$ \\
\hline $\mathbf{4}$ & Cyclone \& Tsunamis & $\begin{array}{c}5700 \mathrm{~km} \text { (out of } \\
7516 \mathrm{~km} \text { long } \\
\text { coastline ) }\end{array}$ \\
\hline $\mathbf{5}$ & Landslides and Avalanche & Hilly areas \\
\hline
\end{tabular}

\section{HERITAGE STRUCTURE OF INDIA}

India has a huge range of Heritages which includes building, monuments, temples, forts, etc. These were made up of different stones bedding and plastering material. They were built several hundred years ago under various Indian Civilizations. These historical monuments are the testimonial of our glorious past. According to UNESCO there are 38 site in India which are considered as world heritage (30 cultural , 7 natural ,1 mixed criteria ) which are conserved under ASI. In Northern states such as Delhi contain major heritages such as Qutub Minar, Red Fort complex, Hamyun Tomb etc. Uttar Pradesh has 12 heritage sites out of which most popular are TAJ MAHAL of Agra \& FATAHPUR SIKRI, IMAMBARA RUMI GATE etc ; Rajasthan and Bihar. Every year it brings lots of tourism into the country and contributes in the economy. They reflect the glory of history from generation to generation.

\section{SCOPE OF DAMAGES}

But today these monuments are losing their beauty and strength. This is because of pollution and various changes which have come in the methods of living of this Industrial civilization.

India has a history of converting their heritage structure to any museum or government offices or hospitals and use them efficiently.

Heritage structures are damaging or can say losing their original reflects is result of following

a) Formation of cracks: Due to vibrations of moving vehicles, changes in land use, due growth of plants, bird menace, support settlement. 
b) Loosening of masonry joint: Due to Eccentric loading and decomposing to material with ageing.

c) Seepage: Dampness to cracks and fissures

d) Erosion: Lead to damage the structural members such as beams and abutments, columns

e) De-Coloration: Caused due to cyclic exposure to sun, rain, winters and frost.

The major Factors affecting the Historical Building are :

i. Natural disaster such as cyclone or earthquake

ii. Erosion caused due to action of the hazardous materials. Also due to growth of vegetation on the buildings

iii. Damages due to aging and adverse environmental factors

iv. National priorities

v. Lack of cleanliness and Regular Maintenance

\section{RETROFITTING}

The process of upgrading the load bearing capacity of existing building to improve its structural performance is termed as Retrofitting. It's the method of restoring the lost strength of structure.

There are varieties of Basic and advance techniques are available to retrofit any structure such Jacketing , Mass Reduction, Base Isolation, Bracing etc.

So looking into the increase in damages and seismic activities many efforts had been made in past decades to restore the strength of heritages to make them capable to with stand seismic forces. Many cosmetic repairs run every day by the concerning authorities aiming to preserve the beauty of stones and material used in heritages (used in constructed by Kings).

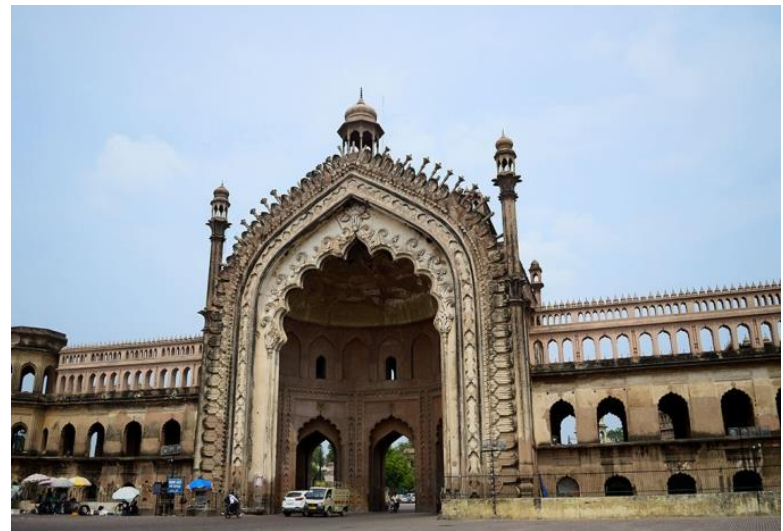

Fig No. 1 : Rumi Gate

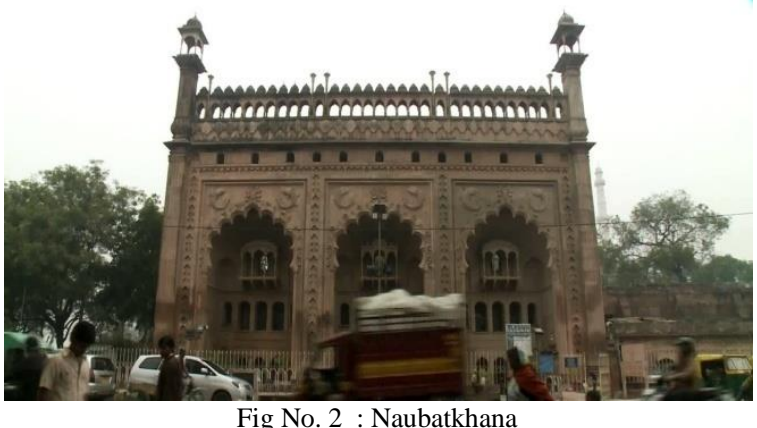

These repairs have helped the structure very well but repairing technique could not stay for long. They deteriorated the original material. Reason behind this failure was repair could not form the efficient bond with existing masonry. In several places the originality of structure has been totally vanished.

\section{STRUCTURAL ASPECT}

After studying the structural design of heritage structure many questions have raised in the minds of structure engineers. Although we have lot many heritage sites which are situated in the severe earthquake zone and cyclone prone areas (such as coastal region of south India) are still into existences, even after been hit by these natural disasters countless times in their life time.

Past civilization had no structural intellect as it is available in today's world but looking into the giant structure constructed, true wisdom of architects and designers of ancient period are reflected. Understanding of structural design discovers that most of the existing heritage buildings are symmetrical in shape with their base wider compared to its top.

It shows that in earlier period, the concept of symmetry was followed with a simple rule of physics which states that 'The resultant force of all the forces acting on the body should lie within middle third from the base region'. To assure the symmetry, the monolithic pattern of Arch and Dome can be seen commonly in Heritage structures. In common, the bases are made wider then top surfaces of monuments; it was done in order to trap the position of neutral axis within the base area when the high structure been subjected to disastrous thrust produced by winds and ground motion. This base enlargement was felt to be enough to accommodate the uplift cause by lateral forces.

\section{MATERIAL ASPECT:}

Apart for structure design the strength of building also depends upon the type and quality of material used for it construction. In earlier Period of time no man made material such as concrete and steel were available to resist the environment load and transfer them efficiently to the foundation.

It is a big challenge for structural engineers to develop the knowledge about finding the similarities in type of material used since every other heritage sites are been constructed in different era by different civilizations which exhibits the unique authenticity of its own culture. So the material used in their construction are also as different as their periods of 
construction i.e. huge scarcity based on the availability (such as huge boulders and rock cutting etc) in the era and also dependent over the type of structural design (monolithic dome carvings) to be constructed.

Therefore it had been tough to generate any standard guidelines to retrofit heritage structures particularly.

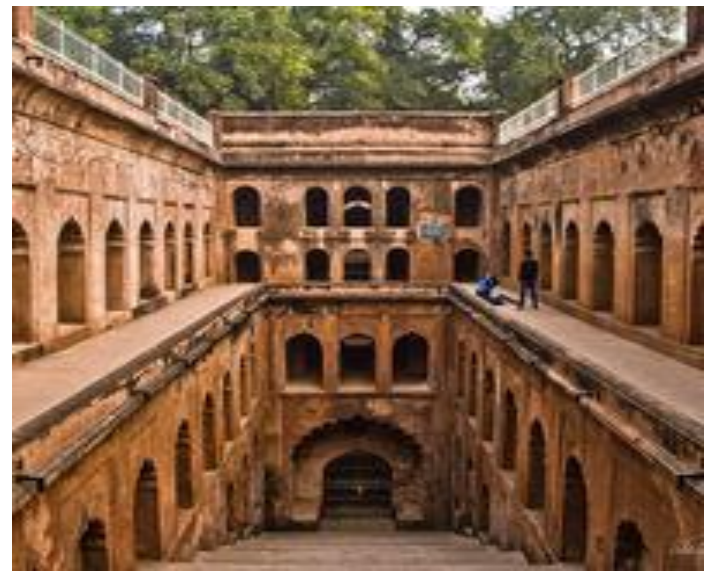

Fig no. 3 : Shahi Boali, Lucknow

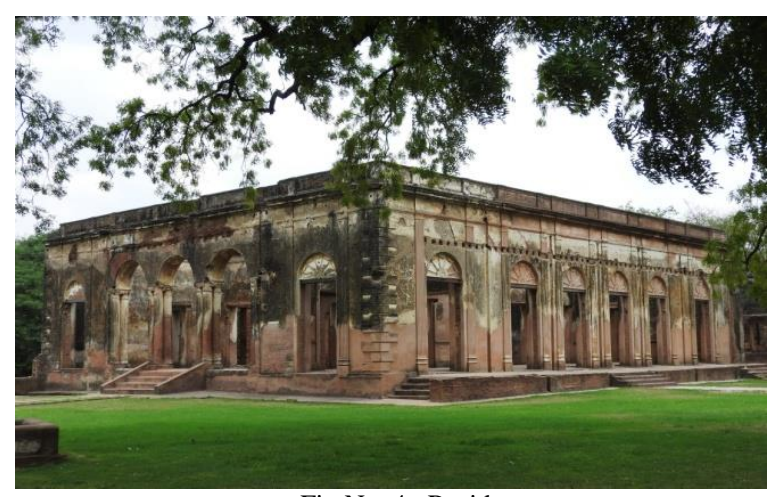

Fig No. 4 : Residency

\section{CASE STUDY: REPAIRING OF AWADHI MONUMENTS}

Previously many attempts have been made by Archeological survey on India to repair the damages occurred in this structure due life style of industrial era. On the basis of studies conducted by IIT Kanpur and researchers who worked over the rehabilitation of Awadhi Architecture has faced a problem.

\section{Problem encountered with Material:}

The material which was used by ASI in the repairing of Rumi Darwaza in Lucknow was failed after some time of application. The repair material which was used in construction did not fit with the quality and basic property of original material. Due to which whatever repair was applied was damaged again. This damage was even poorer as it was compared earlier.

Awadhi monument is made up of Lakhauri bricks and lime crushed brick aggregate. Mortar ratio is approximately 1:2 or $1: 3$ by volume.

The main reason behind the damage of repair work was variation is water absorption property.

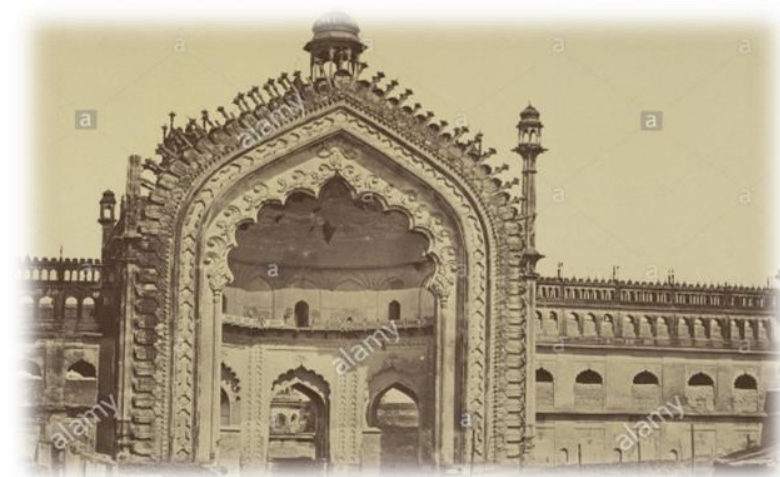

Fig No. 5 : File Pictures of Rumi Gate

\section{Properties of original material:}

Compressive strength of bricks used is approximately lies between $15 \mathrm{Mpa}$ to $17 \mathrm{Mpa}$. Modulus of elasticity was found to be $5.7 \mathrm{Gpa}$.Water absorption is almost $11.4 \%$. Porosity was calculated to be $19.9 \%$.
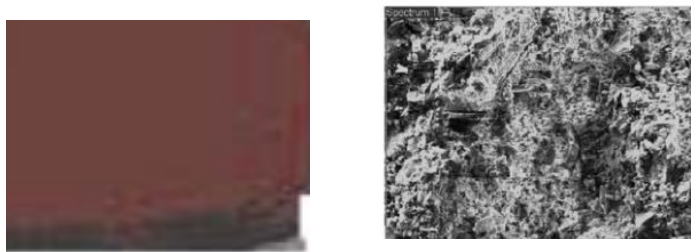

Fig No. 6 : Material

\section{Properties of repair material:}

Contemporary bricks compressive strength is approximately 20.8Mpa. Modulus of elasticity was determined to be close to $6.1 \mathrm{GPa}$. Water absorption is 12.4 $\%$.

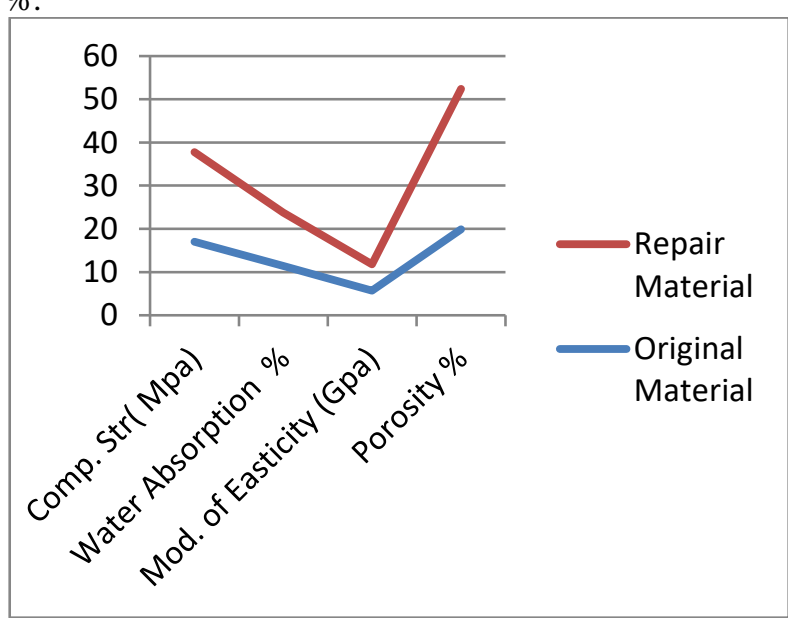

Fig no. 5 : Comparative Chart

\section{Structural Test:}

Structural test of Rumi Darwaza was conducted by the researches in order to make it stronger to with stand the seismic ground motion. During this structural analysis understandability lead the engineers towards the parts of structure which may damage due to ground motion. The crown area which contains major arch and dome was more vulnerable to stresses and moments caused to due seismic 
analysis test. The method of arch bracing was proposed to withstand the stresses which are likely to be developed by ground motion.

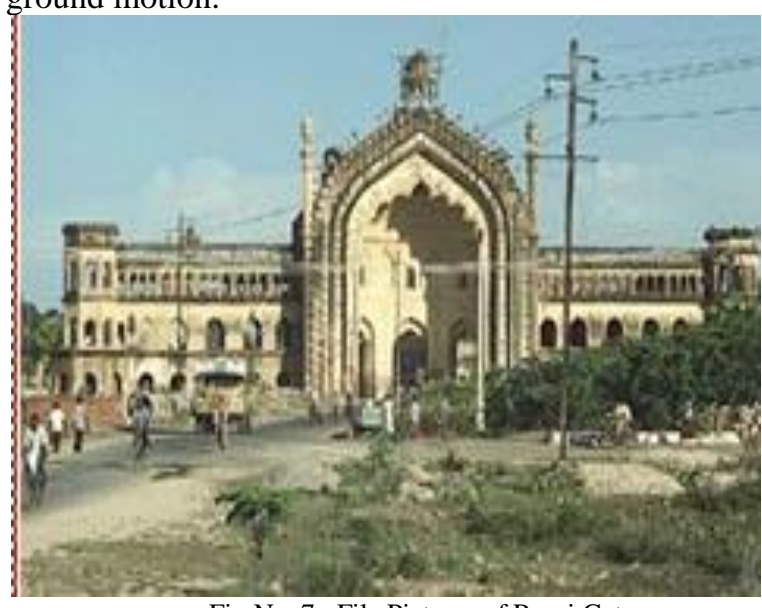

Fig No. 7 : File Pictures of Rumi Gate

To make structure more seismically stronger the retrofitting of the structure was done using the modern technique of jacketing which has changed the original looks to drafted one.

\section{REPAIRING OF TAJ MAHAL, AGRA}

Taj Mahal is one of the most popular heritage monument of India. It's made in year 1631-1648. It was included in the World Heritage site in 1983. Its inscribed as a cultural property of universal significance.
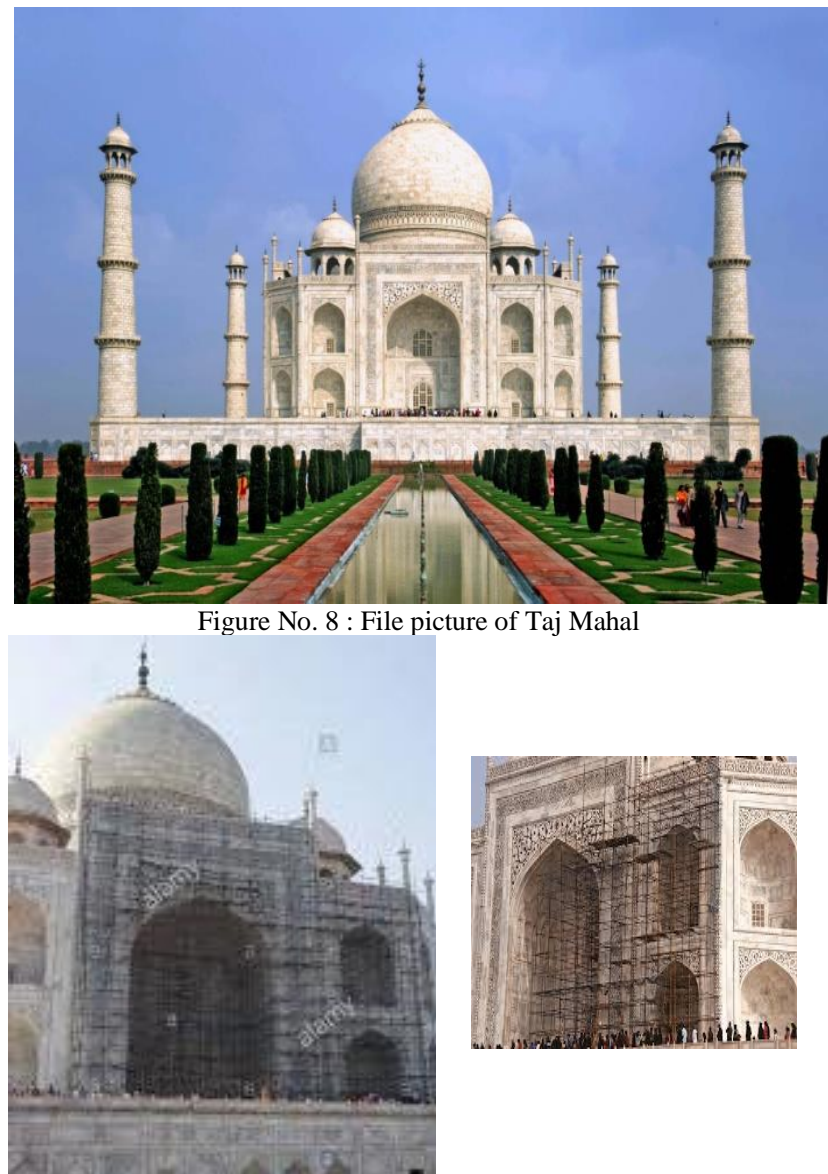

Figure No. 9 : Repairing work
Taj Mahal is the greatest architectural achievement of the whole range of Indo-Islamic architecture. It is situated at the bank of river YAMUNA. Taj Mahal structure contains double dome mausoleum and four Minnars. The whole monument rest over well type foundation filled with rubble masonry. The walls of mausoleum are made up of Lakhauri Bricks with mortar made of lime.

Material : Properties of Lakhuri bricks used for The bricks are examined and the test report is below:-

Table No. 3 : Properties of Brick

\begin{tabular}{|c|c|c|}
\hline \multicolumn{1}{l}{ SIno } & Properties & Values \\
\hline 1 & Colour & Orange $/ \mathrm{red}$ \\
\hline 2 & Water Absorption & $10.13 \%$ \\
\hline 3 & Compressive Strength & $159 \mathrm{~kg} / \mathrm{m}^{3}$ \\
\hline 4 & Crushing Load & $33 \mathrm{MT}$ \\
\hline 5 & Density & $2077 \mathrm{~kg} / \mathrm{m}$ \\
\hline 6 & Size & $18 \times 11 \times 21 / 2 \mathrm{~cm}$ \\
\hline
\end{tabular}

\section{Defect Observed}

Many defects had been observed in the structure with ageing and daily bases movement of crowd and pollution in this industrial world.

Marble: marble got badly affected by the action of polluted environment.
1. Decoloration
2. Crack formation
3. Marble bulging
4. Erosion of marble edges
5. Loss in shinning

Sand stone: Its was badly affected by pollution. It resulted to weight loss, compressive strength water absorption percentage. Reaction with $\mathrm{H}_{2} \mathrm{SO}_{4}$ leads to dark spot formation.

Mortar : Mortar was prepared using lime coarse sand and surkhi (ratio of 1:1:2). Hydraulic lime was used. Mortar used was also added with gur, urd, batasha, basen , juite, gum etc. to produce binding material.

The thickness of mortar joint in this brick masonry was observed almost 2 times the size of brick.

\section{Causes of Defect:}

The caused behind these defects are following.
1. Aging
2. Pollution
3. Foundation settlement
4. Chemical weathering
5. Mineral impurities.

6. Crack formation due to stress developed pressure exerted by structure resting over the base slab.

Structure : Taj Mahal structure contains double dome mausoleum and four Minnars.. The walls of monuments are made of Lakhuri bricks and lime mortar. The main hall and minnars rests over the rectangular base made of sandstone bed. The weight of dome is estimated as 12000 tons which produce compressive stress of 5 tons per sq feets at the base. 
Foundation: The whole monument rest over well type foundation filled with rubble masonry. The thickness of foundation is about $12 \mathrm{~m}$ appox.

The soil mass below it contains the sandy strata of $9.5 \mathrm{~m}$ followed by $65 \mathrm{~m}$ thick layer of clayey soil.

\section{LAWS \& ACTS}

Many Law and Act are been passed by government in order conserve heritage and looks after the remains. Following are listed below

i. The Bengal Regulation XIX of 1810 and the Madras Regulation VII of 1817 are laws which were made in for heritage conservation.

ii. In 1863 Act $X X$ was passed, which empowers the government to conserve structures of historical or architectural value.

iii. The Ancient Monuments Preservation Act, 1904 permits government authority over privately owned heritage structures.

iv. The Ancient Monuments and Archaeological Sites and Remains Act 1958, passed for the preservation of ancient and historical monuments and archaeological sites and remains of national for the protection of sculptures, carvings and other like objects.

v. An amendment in 2010 provided for the constitution of the National Monument Authority charged with the grading and classifying of protected monuments and areas.

vi. The Antiquities and Art Treasures Act 1972 was enacted for effective control over the moveable cultural property consisting of antiquities and art treasures.

vii. India's commitment to heritage was further emphasized when it became a signatory to UNESCO's World Heritage Convention for the protection of global and national heritage.

viii. The Ancient and Historical Monuments and Archaeological Sites and Remains Preservation Act, 1956 of Uttar Pradesh provides for the "preservation of ancient and historical monuments and archaeological sites and remains in (the state) other than those declared by Parliament by law to be of national importance".

ix. In West Bengal, the Heritage Commission Act, 2001 provides "for the establishment of a Heritage Commission in the State of West Bengal for the purpose of identifying heritage buildings, monuments, precincts and sites and for measures for their restoration and preservation".

x. The Tamil Nadu Ancient Monuments and Archaeological Sites and Remains Act, 1966;

xi. Hampi World Heritage Area Management Authority Act, 2002;

xii. Orissa Ancient Monuments and Preservation Act, 1956; the Rajasthan Monuments, Archaeological Sites and Antiquities Act, 1961; xiii. The Madhya Pradesh Ancient Monuments and Archaeological Sites and Remains Act, 1964.

xiv. Archaeological Survey of India (ASI): At the central level, nationally protected monuments fall under the jurisdiction of the ASI. It works under the Ministry of Culture and is responsible for archaeological research and conservation and preservation of around 3,650 monuments categorized as "national heritage". It administers these under the AMASR Act. The Directorate of State Archaeology and Museums looks after stateprotected monuments

India is amongst the countries in the world with the highest risk of natural disasters, ranking third in the number of disaster events, second in the number of disaster victims, and fifth in economic damage on account of natural disasters. These disasters are in the form of earthquakes, fires, floods, cyclones and drought. In recent years, climate change has only increased the risk of disasters.

\section{ECONOMICAL ASPECT:}

Restoration work needs plenty of time and financial resources. . Indeed, in such a situation where people have been killed and homes have been destroyed, heritage structures will not be accorded the top priority.

In India, to begin with, built heritage is under-funded by either public or private sources. Neither are banks and financial institutions keen in extending loans for the protection and development of heritage assets. Banks are wary about putting their money into heritage projects, as the financial viability of such projects is not always easy to establish. "Linkages between heritage conservation and economic development, particularly in the context of promoting tourism, are still being understood, leading banks to be cautious in funding urban heritage conservation projects"

Cess from tourism receipt: Some heritage sites have the potential to generate tourism and their upkeep can help achieve financial viability.

International donors and crowd sourcing: It should also be possible to seek monetary assistance from the World Heritage Fund. Citizens could come forward with voluntary contributions of money, skill and expertise. Other means such as crowd sourcing could provide handsome sums of money.

Heritage properties that are under private ownership pose a particular problem: as they are averse to the listing of their properties as "heritage", they do not fall under the purview of government conservation agencies.

\section{CONCLUSION}

According to understandability of the past efforts of retrofitting Heritage buildings required to be so conserved as close to their original as possible. 
Compatibility with the existing material being repaired and adhesion must guarantee durable jointing effect.

Compatibility of material refers to properties i.e. the mechanical, physical, rheological and chemical features of both the materials must correspond to each other.

Restoration work needs plenty of time and financial resources. During natural disaster where people have been killed and homes have been destroyed, in such a situation heritage structures will not be accorded the top priority. Due to this heritages are left for later to be given attention to.

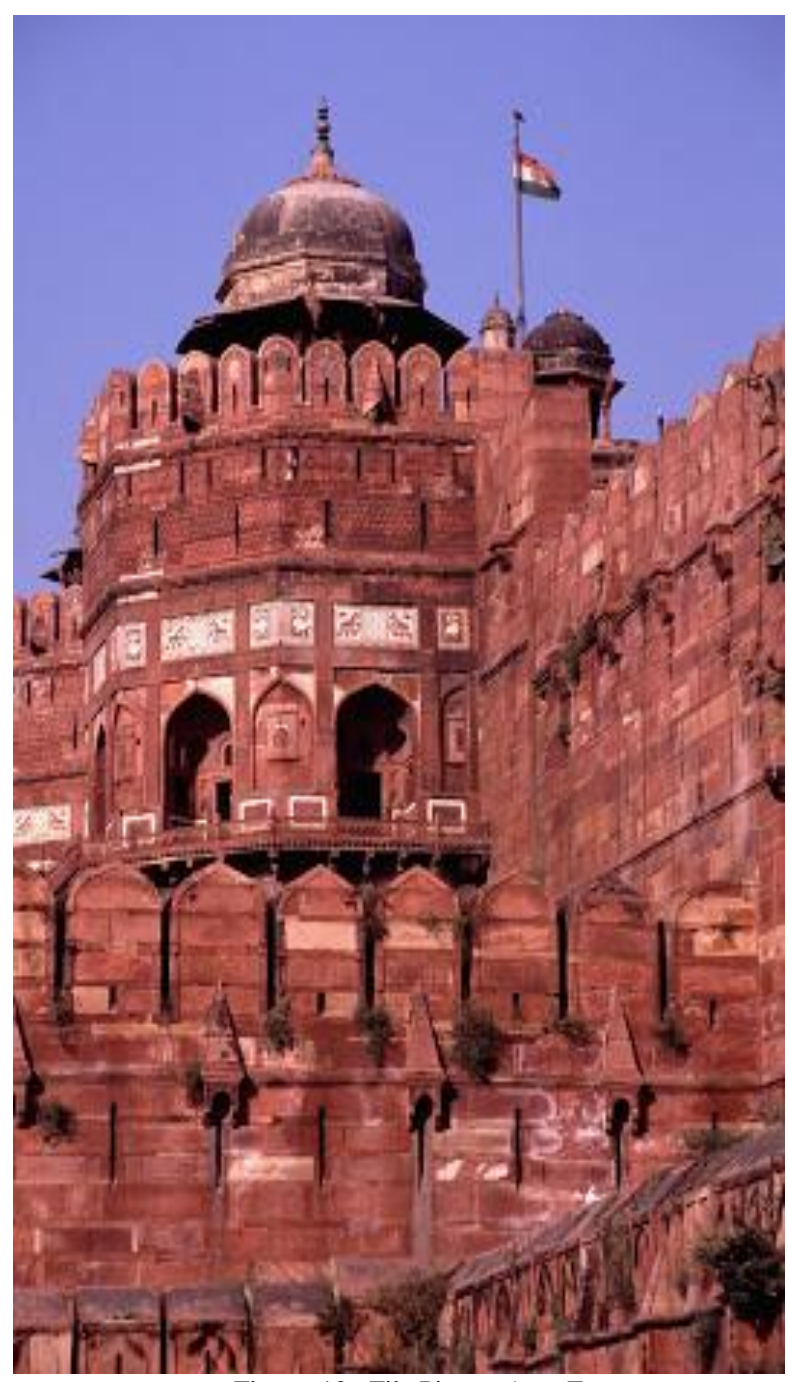

Fig no. 10 : File Picture Agra Fort

\section{REFERENCES}

[1] Bricks and mortars in Lucknow monuments of c. 17-18 century Durgesh C. Rai* and S. Dhanapal Department of Civil Engineering, Indian Institute of Technology Kanpur, Kanpur 208 106, India

[2] Ramanath Jha, "Protecting India's Built Heritage Against Natural Disasters", ORF Issue Brief No. 293, May 2019, Observer Research Foundation.

[3] Taj Mahal : Conservation and Management Dr. D. Dayalan Archeological Survey of India.

[4] ASTM C 67, Standard test method for sampling and testing brick and structural clay tile, American Society for Testing and Materials (ASTM), West Conshohocken, PA, USA, 2007.

[5] IS 3182: 1986, Indian Standard Code of specification for broken brick (burnt clay) fine aggregate for use in lime mortar. Bureau of Indian Standards, New Delhi, 1986.

[6] IS 2250: 1981, Indian Standard Code of practice for preparation and use of masonry mortars. Bureau of Indian Standards, New Delhi, 1981.

[7] Bureau of Indian Standards (BIS). (2002). Indian Standard Criteria for Earthquake Resistant Design of Structures - Part 1: Genera provisions and buildings, IS 1893, 5th Rev., New Delhi, India

[8] Kaushik, H. B., Rai, D. C. and Jain, S. K., Stress-strain characteristics of clay brick masonry under uni-axial compression. J. Mater. Civil Eng. ASCE, 2007, 19, 728-739.

[9] Rai, D. C. and Dhanapal, S. (2015). "Mineralogical and Mechanical Properties of Masonry and Mortars of the Lucknow Monuments Circa the 18th Century." International Journal of Architectural Heritage, 9(3), 300-309.

[10] Chandra, S., History of Architecture and Ancient Building Materials, Tech Book International, New Delhi, 2003

[11] Moropoulou, A., Cakmak, A. S., Bakolas, A., Labropoulos, K. and Bisbikou, K., Properties and technology of the crushed brick mortars of Hagia Sophia. In Soil Dynamics and Earthquake Engineering VII (eds Cakmak, A. S. and Brebbia, C. A.) Computational Mechanics Publications, Southampton Boston, USA, 1995, pp. 651-661

[12] Dynamic Characterization And Seismic Assessment Of Historic Masonry Structure Of Rumi Darwaza Singh, Amanpreet And Rai, Durgesh 